\title{
Teaching EFL in a Rural Context through Place-Based Education: Expressing Our Place Experiences through Short Poems
}

\author{
Pilar Salazar Jaramillo ${ }^{1}$ and Yeyson Espejo Malagon ${ }^{1}$
}

\begin{abstract}
This project implemented Place Based Education (PBE) as the basis to teach English to children from a rural school in Bogota, Colombia. Place Based Education is defined by (Sobel, 2004) as the process of considering not only the community, but also the environment as the beginning to teach concepts related to language arts and other subjects from the curriculum. In the case of our research project; we used PBE to teach English as a Foreign Language to two fourth grade rural classrooms. As for the objectives of our research, the first one sought to explore the role PBE had on approaching EFL students to their rural context and as for the second one, it was aimed to identify and describe the responses students had towards the writing of short poems based on the GenreBased Approach (Hyland, 2007). Regarding the findings of our research project, it was evidenced that Place Based Education connected students to their rural surroundings and developed on them, an emotional bond towards their rural world. Regarding the writing of English, it was shown that the Genre- Based Approach permitted for students to feel confident and enthusiastic while writing in English. Furthermore, as part of the experiences students had with their local and English language, a book with the poems written by the students was created and published.
\end{abstract}

Key words: Place Based Education, Genre- Based Approach, poetry for children, rural context, EFL

\section{Introduction}

Nowadays taking care of the environment has become an important aspect in the field of education. That is why pedagogies such as Place-Based education (PBE) have emerged, PBE is defined by Sobel (2004), as the process of taking into account, not only the community, but also the environment as the beginning to teach concepts related to language arts and other subjects from the curriculum. After analyzing the data collected through our research project, it was found that Place Based Education a valuable perspective to work with in the rural EFL classroom. Bearing in mind the author's definition of Place Based Education, the low consciousness students had towards their rural surroundings, and the fact that students had not had English classes before, we found in Place Based Education a meaningful and useful way to teach English as a foreign language.

Place-Based Education has as an aim to connect classrooms to the places in which the learning process takes place. By using PBE when teaching English, students played a remarkable role by connecting themselves towards their surroundings, creating a special bond to know their rural place and to take care of it. Just as (Sobel,2004) others as (Kostelnik, M. et al, 2015) consider that learning about the world and the place in which learning takes place, should be a relevant aspect for teaching children. As far as this study is concerned, English as a foreign language was understood as the medium to 
guide students to connect themselves to their rural surroundings in order to raise a consciousness towards their rural place while learning meaningful English language.

When talking about place and education, as ways in which students and communities develop a connection towards their place, (Clark, 2008) expresses that "connectedness" to places is related to civil responsibility and stewardship. Having this in mind, PBE can be a very useful tool in the EFL classroom to approach students to their immediate places and to guide them to be responsible good citizens. A way in which EFL learning and the connection to places were interwoven in our research study, was by using poetry writing activities that allowed students to learn to write in English and reflect on their surroundings.

According to (Brown, 1994) the age of students and factors like; the intellectual development, the sensory input, the affective factors and the use of authentic and meaningful language, are important when teaching children. Poetry in our EFL classroom worked with those aspects mentioned by the author, by having the rural place as the main scenario. Referring to poetry, (Watts, 2016) asserts that it can support the development of different prime areas of learning such as; communication and language, physical, personal, social and emotional development. In the light of what the authors mention as important matters when teaching children, it could be found in poetry an educational source that not only we made age appropriate, but also supported different learning areas. Because it is important as expressed by (Ruiz, 2003) to provide students with a valuable literacy environment, poetry was chosen for children as our authentic and valuable material, (Collie and Slater, 1987) to learn English with. As expressed by (Canagarajah, 2006) "Teaching materials have to accommodate the values and needs of diverse settings" (p.20) it is considered that the poems written by us were valuable because they suited student's interests, needs, and context.

Also, the features that poetry offers like; the rhyme, the rhythm, and the alliteration were, as expressed by (Graham, 1992), the "companions" that made learning fun for students in our EFL classroom. "Rhythm, music and songs...warm companions on the journey to a new language" (p.3). (Benton, 1987) and (Andrews and Orme, 1993) assert that children have a natural empathy to rhymes and rhythm, which was evident in our EFL rural classroom. As students were taught how to write in English, they were also heartened to read and know their rural surroundings; this reading encouraged them to be active participants in knowing about their surroundings and writing on them. Place Based Education was a tool that permitted us to guide students to appreciate and learn about their rural surroundings; tit is considered an approach to education that would guide members of the community, and future generations on the path towards the appreciation of their school and their rural context.

\section{Setting and Participants}

This study was held in the public rural school IED RURAL QUIBA ALTA located in Ciudad Bolivar in the village of Quiba. Quiba is a rural village located in the periphery of the south part of Bogota, in which its people still practice their rural customs such as; farming of vegetables and beans. Even though, the whole rural school community is known as Quiba Alta, Campus B is often called Quiba Baja because it is in 
the low part of the village. This research study was done in Campus B which is the preschool and primary branch. Even though the school is in a beautiful rural area, there are evident environmental issues that take place in the rural school surroundings such as: deforestation, garbage and pollution.

Since, we were two preservice teachers, observing and working in our own classrooms, the participants of this study were the students of two fourth grade classrooms. We worked with a total of sixty students. Talking about Quiba Baja primary School in general and the participants of our study, English language was taught to them by primary teachers who only imparted some minutes of the language (15-20 minutes) per week. During those minutes of class, the students were instructed un-situated vocabulary.

\section{Statement of the Problem}

Nowadays, English has become an important matter in Education in Colombia because it brings many opportunities to people to succeed, not only in Colombia, but also around the world. Looking for a way to incorporate English Language in the field of Education of the country, the government has proposed the basic standards on English competences as part of the national bilingual program. In the basic standards, some criteria that should be considered when teaching English are proposed for each grade.

Considering the primary rural school in which our practicum took place, and the fourth grades we observed and worked with, we found that the standards regarding fourth grade, were not being followed by the teachers, but most importantly, we reflected on the fact that English standards themselves seem to be decontextualized from the reality of some schools in Colombia, an example of this are the rural areas of the country in which English language is barely used for authentic purposes Cárdenas (2006). Talking about Quiba Alta primary School, English is taught by primary teachers who only imparted some minutes of the language (15- 20 minutes) per week. During those minutes of class, the students were instructed un-situated vocabulary. In some of our observations, we could witness the teachers instructing students on fruits they did not even recognize or had seen or tasted before, (a kiwi, a peach, a watermelon Etc.)

From the needs analysis we performed in Quiba Alta School, we evidenced that the vocabulary taught to students was not meaningful because it did not have anything to do with their lives Chapetón (2016) (M. Chapetón, personal communication, September 26, 2016) and also because of the way it was conceived in the curriculum, which at the same time seemed to follow standards that were disconnected from the rural context. Not only had we found disconnection regarding language teaching, but also a disconnection of students towards their immediate rural place. After some data collected, the low consciousness students had for their rural surroundings, was evident. Therefore, teaching about place was a meaningful tool in the EFL classroom. When teaching practices become situated, Chala \& Chapetón (2012), not only it ensures that students will follow learning standards, but also that their needs, the place in which education takes place and the social activities of that place, will be considered as important aspects that will make learning meaningful. 


\section{Objectives and Research Questions}

The following research questions and objectives had as a purpose to guide our research study which aimed to use place-based education along with the genre-based approach writing activities in order to teach about the rural place and English as a foreign language to students from a rural school.

\section{Research Questions}

$\checkmark$ What is the role of Place Based Education in approaching EFL students to their rural surroundings?

$\checkmark$ How do EFL students respond to the writing of short poems based on the genre approach, when these poems have their rural context as a core?

\section{Research Objectives}

$\checkmark$ To explore and describe the role that place based education has on EFL students from a rural school when they are approached to their rural context.

$\checkmark$ To identify and describe the response students have towards the writing of short poems based on the genre approach, when these poems have their rural context as a core.

\section{Instructional Design}

The instructional design of our research study mirrors our understanding and reflection on teaching English in a rural context. Three phases (see table 1) were created having the rural place as the subject matter and the short poems as the medium to approach students to English writing and their immediate context. Poetry played an important role within our pedagogical intervention because as (Watts, 2016) describes, poems can encourage children to look "closely at the world around them" and serve as an expression of an experience. We saw in poetry an opportunity to teach on place and invited children to write poems to report on their outdoors experiences, emotions, and the new things they learned about their village.

Table 1. Phases of the pedagogical intervention

\begin{tabular}{|c|c|c|c|}
\hline CYCLE & $\begin{array}{l}\text { TYPES OF } \\
\text { POEMS }\end{array}$ & OВJECTIVE & ESTIMATED TIME \\
\hline $\begin{array}{c}\text { Place } \\
\text { consciousness } \\
\mathbf{1}\end{array}$ & $\begin{array}{l}\text { Poems on } \\
\text { Quiba. } \\
\text { Diamond } \\
\text { poems } \\
\text { Stair poems } \\
\text { Color poems }\end{array}$ & $\begin{array}{l}\text { To approach students to history, } \\
\text { surroundings and flora and fauna from } \\
\text { Quiba Baja village. }\end{array}$ & $\begin{array}{l}\text { Twenty three sessions (About eleven } \\
\text { weeks). Each session: Around } 1 \\
\text { hour and a half. } \\
\text { From February } 29 \text { to September } 13 \\
2016 \text {. }\end{array}$ \\
\hline $\begin{array}{c}\text { Hands on. } \\
2\end{array}$ & $\begin{array}{l}\text { Poems on } \\
\text { environmental } \\
\text { matters. }\end{array}$ & $\begin{array}{l}\text { To recognize environmental issues in } \\
\text { the immediate surroundings and use } \\
\text { hands on activities to reflect on them. }\end{array}$ & $\begin{array}{l}10 \text { sessions (About five weeks). } \\
\text { Each session: Around } 1 \text { hour and a } \\
\text { half. From September } 20 \text { to } \\
\text { November } 8^{\text {th }} 2016 \text {. }\end{array}$ \\
\hline $\begin{array}{l}\text { This is why } \\
\text { love Quiba. } \\
\mathbf{3}\end{array}$ & $\begin{array}{l}\text { Post cards } \\
\text { poems. } \\
\text { Diamond } \\
\text { poems }\end{array}$ & $\begin{array}{l}\text { To present Quiba to people who are } \\
\text { not familiar with its rural context } \\
\text { while reflecting on what was learned } \\
\text { about the place and the importance of } \\
\text { taking care of it. }\end{array}$ & $\begin{array}{l}3 \text { sessions (About two weeks). Each } \\
\text { session: Around } 1 \text { hour and a half } \\
\text { From November } 10 \text { to November } 17 \\
2016 \text {. }\end{array}$ \\
\hline
\end{tabular}




\section{Conclusions}

The objectives within our research study were aimed to describe and analyze the role that place based education had on EFL students from a rural school when they were approached to their rural context, and to identify the response students had towards the writing of short poems based on the genre approach, when these poems had their rural context as a core. Regarding the answer to the first question, the data analyzed evidenced that Place Based Education had two main roles when approaching EFL students to their rural surroundings. In the first place, PBE played an important role by connecting the EFL students to their rural context. As for the second role, PBE nurtured place consciousness on students towards their rural context by developing a place attachment towards the Village of Quiba that approached them to love it and care for it.

As for the second question and the responses students had when writing short poems on the rural context, based on the Genre Based Approach, two responses emerged: On the one hand, the first response is related to the confidence and enthusiasm students evidenced to have while writing in English, this was due, by guiding them with models of poems that helped them to understand and have a clear view on what they wanted to write. Hence, data also evidenced that students felt enthusiastic to write. It was evidenced that they enjoyed writing short poems in English as they had the opportunity to sing, draw, use clay, paint, have field trips, interact with their surroundings and to express themselves freely. Furthermore, the act of writing short poems for students was an emotional and memorable experience because as data reveled, it was something that will be remembered by them.

Referring the second response students had towards a Genre Based Approach, the creation of the book guided students to develop a sense of belonging in the EFL classroom. They felt proud of the outcome and felt happy of being part of the project. Finally, as a result from the making of a book, data also revealed that different prosocial actions such as: helping each other, sharing, and cooperating were developed in the EFL classroom. Because children were guided in a process in which they knew we all were "putting our grain of sand" towards a common goal, they were encouraged to work together and help each other.

\section{References}

Andrew, M. and Orme, D. (1993). The second poetry kit. 1st ed. London: Thornes.

Benton, M. (1978). Poetry for children: a neglected art. Children's literature in education, 9(3), pp.111-126.

Brown, H. (1994). Principles of language learning and teaching. 3 rd edition. New Jersey: Prentice Hall Regents.

Burns, A. (1999) Collaborative Action Research for English Language Teachers.1st ed. Cambridge: Cambridge University Press.

Canagarajah, A. (2006). TESOL at Forty: What Are the Issues?. TESOL Quarterly, 40(1), p.9.

Cárdenas, M. L. (2006, September). Bilingual Colombia: Are we ready for it? What is needed? In 19th Annual EA Education Conference.

Chala, P. and Chapetón, C. (2012). "EFL argumentative essay writing as a situated-social practice: A review of concepts". Folios, 1(36), pp.23-36. 
Clark, D. (2008). Learning to make choices for the future: Connecting public lands, schools, and communities through place-based learning and civic engagement. Center for Placebased Learning and Community Engagement.

Collie, J. \& Slater, S. (1987). Literature in the language classroom: a resource book of ideas and activities. Cambridge: Cambridge University Press.

Dewey, J. (1929). The later works: How we think. Southern Illinois. field settings. Skokie: Rand McNally College

Graham, C. (1992) Prentuce-Hall, Inc. "singing, chanting, telling tales, arts in the language classroom" (Pp. 3 , 43)

Hyland, K. (2007). Genre pedagogy: Language, literacy and L2 writing instruction. Journal of second language writing, 16(3), 148-164.

Kostelnik, M., Whiren, A., Soderman, A., Rupiper, M. L., \& Gregory, K. (2015). Guiding children's social development and learning (8th edn.). Stamford, United States: Cengage Learning.

Ruíz, N. (2003). Kid watching and the development of children as writers. Universidad Distrital Francisco José de Caldas, profile

Sobel, D. (2004). Place-based education: Connecting classroom and community. Nature and Listening, 4.

Watts, A. (2016). Exploring Poetry with Young Children: Sharing and Creating Poems in the Early Years. Routledge. 